\title{
Teaching reform and practice of brand management based on entrepreneurial orientation and PBL model
}

\author{
Li Wang \\ School of Economics and Management Xijing University , xi'an ,710123
}

Key words: entrepreneurial orientation; PBL model; brand management; teaching reform

\begin{abstract}
China's social market economy, the brand is gradually showing its strong power, but also more and more reflected in all aspects of life, it is the soul of the enterprise, brand concept deeply rooted in the hearts of the people. As one of the most important courses in the college curriculum, brand management is very practical and comprehensive in social life. The entrepreneurial orientation and use of PBL teaching mode in the course of brand management, bring the new teaching model and brand management in curriculum teaching, through the course teaching reform and practice, cultivate brand management more talents for the society.
\end{abstract}

\section{Introduction}

In the era of information, the strength of the brand continues to grow, it supports a business, and even a nation. So the importance of brand management is self-evident [1]. As a very important course, brand management has a strong social practice and comprehensive application . As for the entrepreneurial orientation and PBL mode of teaching reform of this course in the teaching mode, the entrepreneurial orientation can guide the students in the management of independent action, innovation, bold practice, face the challenge, and constantly improve their social skills in innovation practice, the challenge is to hone the will; and the PBL pattern is to cultivate the students comprehensive ability, bid farewell to the traditional education model, promote independent learning, through the design of complex teaching scenarios, allowing students to independent research and in-depth study of the situation, mining the hidden knowledge, the ultimate solution to the problem.

\section{Analysis on the present situation and problems of 2 brand course teaching}

Brand management is a comprehensive, applied and practical discipline, so we must pay enough attention to [2] in classroom teaching. However, at this stage of the brand course of the single teaching mode in the teaching process, teaching methods for teachers in the classroom only, for the theory of knowledge students about brand curriculum, teaching content is simple, although teachers can reasonable use in multimedia teaching, but it is only in the visual feeling let students satisfied, enhance students for some brand prominent stereo feeling, but the teacher in the classroom for some examples of teaching teachers lack of interest, and cannot form the interaction with the student, the teaching quality and efficiency is very poor. However, due to the lack of practical content teaching, students can not combine theoretical knowledge with social practice, students' practical ability and comprehensive application ability can not be improved. Although the students to master a variety of 
theoretical knowledge, but not practice promotion, so students for brand management courses can not be simple and will lose his interest in learning, this way of teaching both students and teachers occupy a lot of time, and did not reach the ideal teaching effect

The teacher is not only for students who are teaching, along the way for students to guide people, so directly affect teachers ability level of the students' comprehensive ability [3]. Teachers in the teaching process, need to invest a lot of effort to seriously study the theoretical course books, prepare the necessary knowledge of curriculum courseware for students, but also to prepare a number of examples in the classroom for students to explain, but also ensure that the classroom active and vivid, maintain good interactive communication between teachers and students. Brand management courses not only pay attention to theoretical knowledge, but also pay more attention to practical application. In the process of teaching, teachers often only pay attention to the theoretical knowledge and explain, and ignore the exploration and research of practical content, which makes it difficult for students to grasp the comprehensive application of theory and practice. The characteristics of brand courses need to focus on the effective combination of theory and practice. In teaching, the disconnection between theory and practice has a serious impact on students' ability to operate and think independently. Some of them have some theoretical knowledge of teachers, lack of practical experience, like Zhao Kuo, only know how to speak on the battlefield, but it is not practical tactics.

Although the modern educational model has improved, but still can not get rid of the shackles of traditional education mode. Brand management curriculum is gradually moving towards the combination of theory and practice, and constantly cultivate students' independent thinking ability and practical ability. Although some schools began to pay attention to practice teaching, in the school to establish a variety of laboratory, in order to cultivate students' comprehensive ability. But most of the schools have followed the traditional teaching model, assessment methods is simple examination, although it can test students for master degree of theoretical knowledge, but it can only reflect the students' memory ability and testing ability, not the real objective reflection of students' professional skills and mastery of professional knowledge, test methods this simple will slowly kill the students' ability of creative and independent thinking, can not really for the school and the society to develop a comprehensive talent [4].

\section{Teaching reform practice and exploration}

Under the background of the modern era, the school is more and more attached importance to the cultivation of management talents. The teaching reform and practice of brand management course are urgent. In the process of teaching in the course of trademark management, business oriented brand management strategy to expand the real simulation practice teaching in students' learning, the establishment of virtual brand management scenarios, students related roles, complete the whole process of brand management. In addition, brand management teaching should adopt PBL mode, teaching method of problem oriented, this model pays attention to the students"s learning initiative, able to find problems in practice the problem, to solve practical problems through autonomous 
learning. In a word, the reform of brand management should be carried out, and the functional ability of students can be improved.

In the course of brand management, the teaching of theoretical knowledge in the book is indispensable, but because of the practicality and application of brand management, it is necessary to enrich the teaching methods.

Improvement theory teaching. For most students, it is relatively easy to learn and master the theoretical knowledge, and do not need to spend too much time on imaginary knowledge. Brand management course teaching of theoretical knowledge on the Internet can be found everywhere, this brand of learning for students in curriculum theory provides a convenient, and reduces the teachers in the classroom on the theoretical knowledge of redundant complex explanation, the role of the network is to reduce the students don't listen carefully in class, play mobile phone, dozing, chat and other phenomena, shorten the the teaching of theoretical knowledge, improve the efficiency of classroom teaching. Teachers can arrange the time saved carrying out practical activities, including indoor and outdoor activities. Teachers in the explanation of speculative knowledge, and students are not listening to active learning, but forced learning, the passive listening, make students become lazy, no hands, no brains, no learning, no thinking, all [5]. Teachers should create more opportunities for students to enable students to become masters of the classroom, let the students to speak, to express their views and opinions, mobilize the initiative of students, improve the students' ability of thinking, cultivate students' creativity and divergent thinking ability.

Strengthen classroom practice. Brand management course in the theory of knowledge in the teaching process, teachers should be targeted by an example and simulation, business oriented brand management simulation practice teaching examples for students after stepping into the society and to management positions, has important significance. Aside from single theory teaching, practice teaching can guide students to make reasonable analysis for all kinds of situations, students can find problems in various situations, using the theory of knowledge, through mutual discussion between students thinking seriously, through the summary and analysis, the ultimate solution to the problem. In such a process, students cannot only think independently, but also cooperate with each other to explore, improve the students"s innovation ability and practical ability, more conducive to the improvement of students' Comprehensive Citation ability. In addition, the practice of brand management business oriented teaching process, teachers should actively create situations for students, then ask the students to give free group, each group released a variety of tasks, and then let the students according to the teacher issued the task of designing a brand, including brand design, brand operation, brand promotion etc. the whole process, teachers do not participate in, completed by students independently, including data collection, material preparation, discussion between groups and the final design results, students to summarize and to slide in the form of class one by one [6] display. Through the comparison between the groups, scoring selection, the final selection of the best team in brand management. Students in the whole process and mutual supervision, not plagiarism. In this way, not only the students to grasp the theoretical knowledge of more solid, more profound understanding of the knowledge, but also cultivate the students"s innovation ability and 
ability to express. Through the comparison between groups, but also allow students to indirectly feel the fierce competition in the community.

Strengthening extracurricular practice. The importance of classroom theoretical knowledge and practical teaching need not be repeated, and the practice of extracurricular has a great significance for students to master the course of brand management, which is helpful for students to master the knowledge of trademark management [7]. The PBL model is well applied in the extramural practice teaching. For example: the teachers can set up a theme, in accordance with the theme of good students study direction, wanted to examine the problem, go into the market with the problem, collect all kinds of brand on the market, market analysis of various brands, the actual understanding of the various brand marketing strategy, how to promote the brand in the market, and how to carry out strategic adjustment and so on. Through the comprehensive analysis of the market brand, the content of each phase of practice, summary analysis report, the results of the survey report. The teacher carries on the inclusive appraisal to the student practice content, the summary analysis report and the investigation result as well as the practice activity complete situation. If the school conditions allow, can cooperate with some enterprises, let the students learn and practice of brand management to the enterprise on a regular basis, do a summary and record, and the enterprise brand management and put forward reasonable suggestions. Practice of extra-curricular activities, help students find the classroom can not find the problem, which is convenient for students to do theory and practice, to supplement lack of theoretical knowledge in the classroom, is conducive to the realization of the campus to the smooth transition between enterprises. The teaching content and teaching experience of teachers have been enriched and diversified [8].

In the traditional teaching mode, the examination method of the students is mainly the test paper. Therefore, to change the traditional assessment methods, the combination of theory and practice, not only to be reflected in the everyday teaching, but also reflected in the examination. In the past do not pay attention to the practice of examination, the test results of students who are in good accordance with the theoretical knowledge of the master, while ignoring the functional ability of the test. Therefore, the comprehensive ability of students must be reflected in the theory and practice. In the exam, it consists of three parts: theoretical knowledge, brand management case analysis and simulation, brand management practice investigation and analysis, the proportion of each part in accordance with 4:2:4. Analysis of the case of brand management and simulation of the main criteria for the students to refer to the case analysis is rigorous in place, to be able to get the loss of management. In the process of brand management in the actual effect of the standard for evaluation survey and analysis activities mainly refer to students, whether can the brand into the market, the ability to expand the brand management, the enterprises can create greater value for [9], and to the stage of the analysis and summary.

Increase teachers' practical experience. Although the teachers in the classroom can accurately explain the theoretical knowledge, but a lot of practical experience is very lack of teachers, which seriously affect the improvement of students' practical ability, and ultimately affect the quality of teaching. Therefore, teachers should improve the teaching experience and practice experience. Theoretical knowledge will hardly change, change is the content of practice, so teachers should 
constantly learn and improve teaching ability changes in practice. The school can let the teacher to the different enterprise to carry on the practice study, because the teacher of the theory knowledge grasps the degree to be deep, they study the practice content is easier. They need to be able to combine theoretical knowledge with practical activities, and when they return to the classroom, they are more specific and vivid in the course of brand management. Teachers can also connect with each other through practice, learning and academic exchanges.

\section{Conclusion}

In a word, the teaching reform of brand management courses, according to the development of the times, combined with the characteristics of the subject, improve the traditional teaching mode, the theory and practice of the teaching mode of the combination, on the basis of the theory in the practice of bold innovation, make the teaching quality brand management course strive for further improvement.

\section{References:}

[1] Hafeez M H, Shariff M N M, Lazim H B M. Relationship between Entrepreneurial Orientation, Firm Resources, SME Branding and Firm’s Performance: Is Innovation the Missing Link?[J]. American Journal of Industrial \& Business Management, 2012, 2(4):153-159.

[2]Fuentes-Fuentes M D M, Bojica A M, Ruiz-Arroyo M. Entrepreneurial orientation and knowledge acquisition: effects on performance in the specific context of women-owned firms[J]. International Entrepreneurship \& Management Journal, 2015, 11(3):695-717.

[3]Renton M, Daellenbach U, Davenport S, et al. Finding fit: An exploratory look at SME brand orientation and brand management in the New Zealand food and beverage sector[J]. Journal of Brand Management, 2016, 23(3):1-1.

[4]Wang T, Guo R. An empirical study on brand strategy decisions in Chinese companies based on environmental uncertainties and entrepreneurial orientation[J]. Frontiers of Business Research in China, 2007, 1(3):401-421.

[5]Chuchalin A, Minin M, Vyuzhanina N. Practice-oriented learning as a means of increasing adaptability and quality of engineering education[C]// International Conference on Interactive Collaborative Learning. IEEE, 2013:571-574.

[6]Tan S S, Ng C K F. A problem-based learning approach to entrepreneurship education[J]. Education + Training, 2006, 48(6):416-428.

[7]Hmelo C E, Gotterer G S, Bransford J D. A theory-driven approach to assessing the cognitive effects of PBL[J]. Instructional Science, 1997, 25(6):387-408.

[8]Tan S S, Ng C K F. A problem-based learning approach to entrepreneurship education[J]. Education + Training, 2006, 48(6):416-428.

[9]Lin S Y, Overbaugh R C. Computer-mediated discussion, self-efficacy and gender[J]. British Journal of Educational Technology, 2009, 40(6):999-1013. 